\title{
INATIVAÇÃO DO VÍRUS DO MOSAICO COMUM DO FUMO PELO FILTRADO DE CULTURAS DE TRICHODERMA sp. (1)
}

R. Forster ( $\left.{ }^{2}\right)$

Engenhciro agrônomo, Seç̧ão de Genética, Instituto Agronômico de Campinas

\section{1 - INTRODUÇÃO}

Os microrganismos têm sido experimentados frequentemente como inativadores de vírus. Johnson e Hoggan (2) foram os primeiros a empregar o fungo Trichoderma sp. para inativar o vírus do mosaico comum do fumo, adicionando extrato de plantas infetadas pelo vírus ao meio de cultura do fungo. Tecidos vegetais, de plantas infetadas, foram utilizados com a mesma finalidade. Esses autores verificaram que o fungo Trichoderma sp. não é um inativador excepcional de vírus, apesar de sua grande capacidade de destruir celulose. Weindling (6) menciona Trichoderma sp. como produtor de substâncias tóxicas contra outros microrganismos, tendo isolado posteriormente o princípio ativo dêsse fungo $(\mathbf{7}, \mathbf{8}, \mathbf{9})$. Waksman e Horning (5) isolaram dois "strains" dentro do grupo Trichoderma sp., ambos com propriedades antagônicas às bactérias, se bem que não tenham constatado ação totalmente eficiente, em seus ensaios.

No presente trabalho são apresentados alguns resultados de inativação de vírus do mosaico comum do fumo, contido em extratos líquidos de plantas de fumo infetadas empregando, como inativador, filtrados de culturas de Trichoderma sp. crescidas em meio líquido.

\section{2 - MÉTODOS}

Nos ensaios adiante relatados usou-se um "strain" do vírus do mosaico do fumo que vinha sendo empregado nos trabalhos experimentais no Departamento de Fitopatologia da Universidade da Califórnia, em Berkeley. Das plantas de fumo infetadas com êsse "strain" do vírus, coletaram-se as fôlhas, que foram mantidas em cubas de vidro, em compartimentos com temperatura abaixo de $\mathrm{O}^{\circ} \mathrm{C}$, até o momento de serem utilizadas.

A fim de preparar o extrato contendo o vírus, as fôlhas infetadas foram moídas em um picador de carne, após receberem 3 por cento, em pêso, de $\mathrm{K}_{2} \mathrm{HPO}_{4}$ em po, como "buffer". O material picado foi espremido e o líquido filtrado a grosso, em tecido-pano de malha fina, foi submetido à centrifugação a 2500 rotações por minuto em ambiente de laboratório, durante

(1) Trabalho executado no Departamento de Fitopatologia da Universidade da Califórnia, EE. UU., da qual o autor recebeu uma bôlsa de estudos em 1945.

(2) O autor agradece ao Prof. T. E. Rawlins, do Departamento de Fitopatologia da Univ. da Califórnis, a orientação dada na execução déste trabalho. 
30 minutos. Posteriormente, o líquido foi filtrado em "celite filter" e, finalmente, em um filtro Berkefeld-V. Após esta operação, pequenas amostras, colocadas em tubos de ensaio, foram mantidas em temperatura próxima de $\mathrm{O}^{\circ} \mathrm{C}$, aguardando uso. A fim de se comprovar se o extrato não fôra contaminado por microrganismos, foi submetido a teste pela inoculação em meio de cultura, em caixas de Petri, mantidas em estufas a $22^{\circ} \mathrm{C}$.

A cultura monospórica do fungo foi preparada em frascos de Erlenmayer, em meio líquido, para obtenção do filtrado contendo o inativador. Quando a cultura do fungo se mostrou suficientemente desenvolvida, os frascos foram esterilizados a $110^{\circ} \mathrm{C}$ e, posteriormente, mantidos em geladeira a $0^{\circ}$ C. Para ser usado em mistura com o filtrado contendo vírus, o meio de cultura líquido foi filtrado em papel de filtro, com o fim de eliminar os esporos e micélios, agora já mortos pela esterilização mencionada. Salvo menção ao contrário, a mistura dos dois filtrados, isto é, um contendo o vírus e outro contendo o inativador, atingiu a diluição de 1:10. As inoculações dessa mistura em plantas sadias, a fim de se submeter a inativação a teste, foram efetuadas com um pincel pequeno, de pêlos moles, que era molhado na mistura e esfregado sôbre as fôlhas das plantas.

Para êsses testes foram empregadas plantas de Nicotiana glutinosa inoculando a metade longitudinal da esquerda da fôlha com a mistura de inativador e vírus, e a metade da direita com o filtrado das plantas inoculadas contendo o vírus.

Os quadros 1 e 2 contêm os resultados, em números de lesões locais obtidas pelas inoculações. Inicialmente, as fôlhas inoculadas em cada planta foram numeradas. Em vista, porém, do fato de que a variação em número de lesões locais não se mostrou influenciada pela posição relativa da fôlha na planta, as contagens foram agrupadas para cada um dos tratamentos. Os resultados são expressos em percentagens do número de lesões locais obtidas do tratado sôbre o testemunha.

\section{3 - INATIVAÇĀO DO VÍRUS}

O fungo Trichoderma sp. foi cultivado em frascos de Erlenmayer contendo um meio líquido, de acôrdo com Weindling (6) e composto de 2,5 gramas de glicose, 2 gramas de bactopeptona, 2 gramas de $\mathrm{KH}_{2} \mathrm{PO}_{4}, 1$ grama de $\mathrm{MgSO}_{4}, 0,1$ grama de $\mathrm{FeCl}_{3}$ em 1000 centímetros cúbicos de água, e pII próximo de 5. A primeira experiência foi tentada com uma cultura tendo cinco dias de crescimento, posta em autoclave, tendo um $\mathrm{pH}$ de 4,6 no filtrado. Este filtrado foi separado em duas partes. Em uma delas foi mantido o $\mathrm{pH}$ original ; na segunda, ajustou-se o pH para próximo de 7 . Posteriormente, cada parte foi misturada ao extrato de planta contendo o vírus. Diversas misturas assim preparadas permaneceram em laboratório durante tempos variáveis. Para cada $\mathrm{pH}$ diferente, o tempo de permanência da mistura no laboratório, antes da inoculação, foi, respectivamente, de uma hora, trinta minutos ou por um espaço de tempo exatamente necessário para ser operada a mistura, isto é, aproximadamente dois minutos. 
Utilizou-se como testemunha o mesmo extrato das plantas contendo o vírus, diluído em água esterilizada, a 1:10.

Os resultados estâo resumidos na parte superior do quadro 1.

Quinino 1.- Número de lesões observadas em metades de fôlhas de Nicotiana glutinosa, inoculadas com sueo de plantas tratado ou não com o inativador obtido no filtrado de cultura de Trichoderma sp. em meio líquido

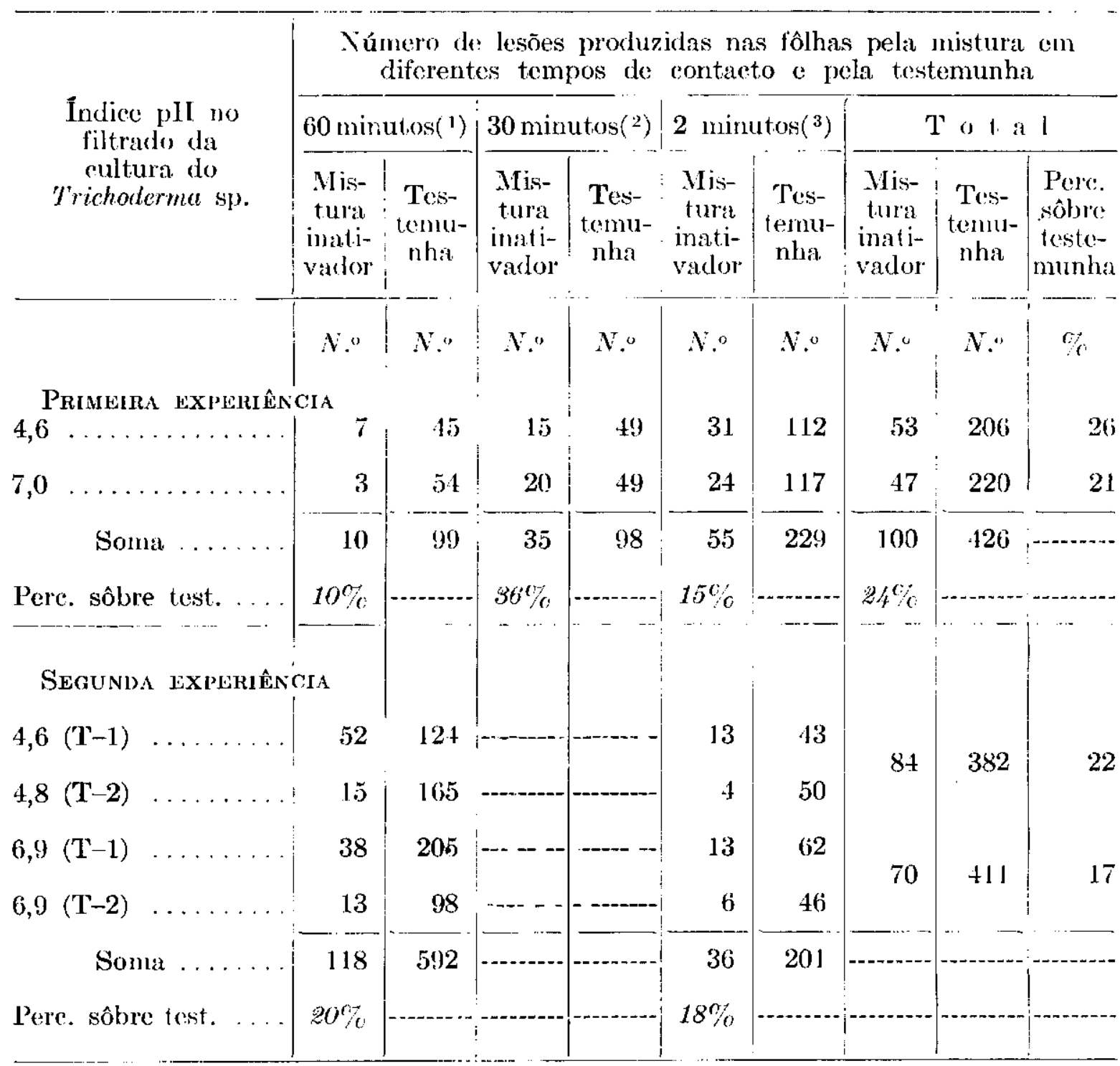

(') e (2) Dados baseados em inoculações em quatro metades de fôlhas. ( $\left.{ }^{3}\right)$ Os dados da primeira experiência se referem a oito metades de fôlhas inoculadas; os dados da segunda se basearam em apenas cinco metades de fôlhas.

Como se pode ver, não houve diferença sensível de ação para os filtrados com diferentes $\mathrm{pH}$. Da mesma forma, a diferença de tempo de contacto na mistura de inativador e vírus não revelou resultados consistentes. Isso ainda é comprovado por inoculações feitas em três outras plantas utilizando as misturas de uma hora e de dois minutos de permanência, sendo cada mistura inomılada, separadamente, cm doze metades de fôlhas, 
do que resultaram 37 lesões para a mistura de uma hora c igualmente 37 lesões para a mistura ${ }^{-1}$ de dois minutos" de permanência, apresentando ambas $\mathrm{pH} 4,6$, e 38 e 35 lesões locais respectivamente, quando o pII era de 7,0 .

Em outra experiência, foi usada uma cultura que apresentava o filtrado com pH 4,6 após 38 dias de crescimento do Trichoderma sp., e a segunda com pH 4,8 após 24 dias de desenvolvimento do fungo. Essas culturas são denominadas, respectivamente, $\mathrm{T}-1$ e $\mathrm{T}-2$ no quadro 1 (scgunda experiência). Uma parte de cada filtrado foi ajustada a pH $6,9 \mathrm{com}$ o uso de $\mathrm{NaOH}$ a 0,5 N. Em seguida, cada uma delas foi misturada ao extrato de planta com vírus, permanecendo, eada mistura, durante uma hora, como anteriormente, e outra amostra sòmente pelo tempo de operação. Os resultados se acham resumidos na parte inferior do quadro 1. 'Também nesta, os resultados foram semelhantes aos da primeira experiência.

\section{1 - ENVELHECIMENTO DE CULTURAS PARA A PRODITCÃO DO INATTVAIOOR}

As culturas de T'richoderma sp. foram preparadas em frascos de Erlenmayer, com esporos isolados. Uma série de frascos permaneceu no laboratório à luz do dia, em temperatura aproximada de $22^{\circ} \mathrm{C}$, e a outra série em uma cstufa a $27^{\circ} \mathrm{C}$, em ambiente escuro. Fsta última série nunca deu formação a esporos durante todo o tempo de desenvolvimento das culturas. No entanto, quando alguns dêsses frascos foram retirados da estufa e expostos à luz do dia, observou-se a produção de esporos, dois dias após essia opcração.

No estudo do envelhecimento das eulturas para a produção do inativador, tomou-se, cada dois dias, um fraseo de cada uma das duas séries, os quais foram postos em autoclave durante 30 minutos. Depois de resfriados, foram mantidos em geladeira, a $0^{\circ} \mathrm{C}$. Conservou-se, igualmente, na geladeira, amostra do meio de cultura original antes de ser inoculado com o fungo. Depois de interrompido o crescimento das culturas em escala sucessiva de tempo, tendo cada grupo de dois frascos uma idade diferente de desenvolvimento, foram realizados os testes, a fim de verificar a relação entre o tempo permitido para o desenvolvimento do fungo e a quantidade de inativador produzido em ambas as sćries, isto é, na série conservada à luz do dia e na conservada no eseuro.

Uma primeira série de inoculações, indicada no quadro 2, foi cfetuada pelo tratamento do suco contendo o vírus com os filtrados de culturas de três idades diferentes, isto é, T-6 com 2 dias; T-12 com 14 dias e T-16 com 22 dias (mantidas no incubador durante o desenvolvimento da cultura) e depois disso posta em autoclave e conservada $\mathrm{em}$ geladeira até o momento de ser usada, e duas culturas provenientes de crescimento do fungo à luz do dia, a saber: T-19 com dois dias e $\mathrm{T}-21$ com catorze dias. De cada filtrado da cultura do fungo retirou-se uma amostra que foi ajustada a $\mathrm{pH}$ acima de 6,5. O extrato de plantas contendo o vírus foi tratado, portanto, com amostras de filtrados de cultura do fungo com idades diferentes de crescimento e com diferentes $\mathrm{pH}$. Posteriormente, realizou-se uma. 
QUADRo 2.- Resultados de inoculações em fôlhas de Nicotiana glutinosa com suco de plantas infetadas com vírus, tratado com filtrado de culturas de Trichoderma sp. com diferentes idades, mantidas em ambiente escuro e à luz do dia. Inoculações efetuadas logo após a mistura do suco com o filtrado inativador

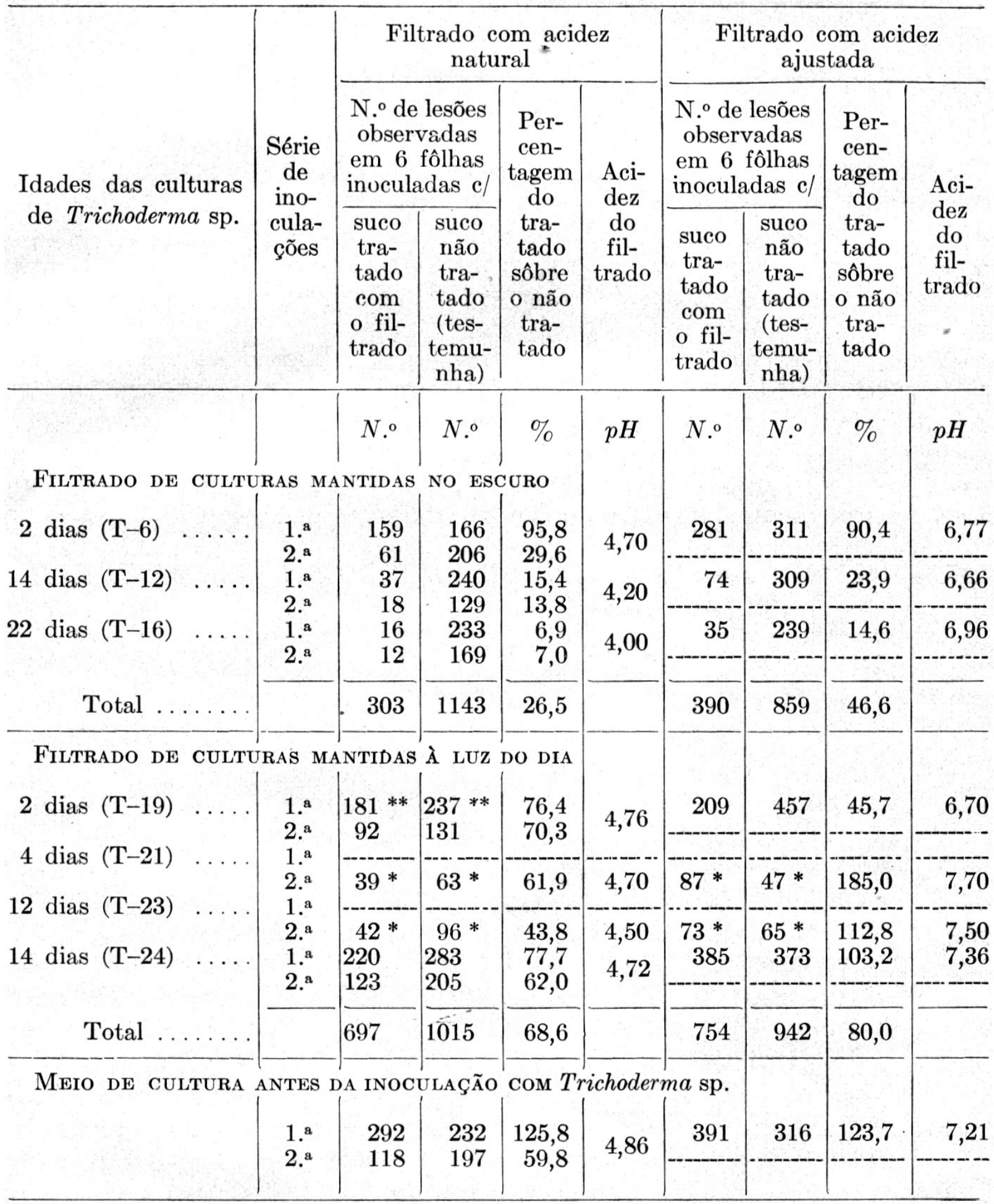

*. = número de lesões em 4 fôlhas inoculadas

** = número de lesões em 5 fôlhas inoculadas 
segunda série de tratamentos, repetindo alguns dos filtrados usados na primeira série e tomando outros, com diferentes idades de desenvolvimento do fungo. Vê-se, pelo quadro 2, que, aparentemente, o grupo de frascos de culturas cultivadas no escuro mostra um crescimento contínuo na produção de inativador, a julgar pela diminuição progressiva no número de lesões locais produzidas. Por outro lado, a série com pII baixo, mantida sob a luz, mostra relativo aumento até o décimo segundo dia, após o que houve diminuição. Todavia, para filtrados cuja acidez foi ajustada a $\mathrm{pH}$ clevado, nessa série mantida sob a luz, os resultados foram inferiores aos obtidos com as amostras de pII baixo, com exceção das culturas com dois dias de crescimento. Scgundo Weindling (8), a toxina que age sôbre os fungos é produzida dentro dos primeiros dois dias e meio de crescimento, depois do que a toxicidade do filtrado não aumenta mais. A toxicidade pode ser perdida depois dêsse período, devido à produção de esporos, que se inicia dentro dêsse espaço de tempo. Porém, quando a vegetação se realiza em ausência de luz, não há produção de esporos, pelo que a toxicidade se mantém $\mathrm{cm}$ crescimento proporcional ao tempo de vegetação da cultura, dentro do período de tempo das presentes experiências, isto é, até 22 dias. Ainda comparando ambas as situações, a cultura mantida no escuro inicia a produção do inativador tardiamente, o que se evidencia pelos resultados dos filtrados $\mathrm{T}-6$ e $\mathrm{T}-19$, originados de culturas de dois dias de crescimento, mas em ambientes difcrentes de exposição à luz.

\section{2 - ISOLAMENTO DO INATIVATOR PRODUZIDO POR TRICHODERMA sp.}

O método seguido foi o mencionado por Weindling e Fmerson (9), com o uso do clorofórmio. As culturas mantidas no escuro, supostamente sob as melhores condições de cultivo, de acôrdo com os resultados anteriores, foram filtradas $\mathrm{cm}$ papel de filtro, para separação de micélio.

O filtrado, uma vez limpo de micélio, foi tratado com clorofórmio, três vêzes consecutivas, sendo o volume de clorofórmio de 0,1 do volume do filtrado, por vez. O filtrado, misturado ao clorofórmio, foi agitado durante, aproximadamente, 10 minutos cada vez. Em seguida, o filtrado foi separado em filtro de separação e evaporado ou destilado. A destilação não se processou até o desaparecimento completo do clorofórmio, mas, sim, deixando sempre pequena quantidade de clorofórmio. No final, todo o líquido foi transferido para cápsula de porcelana, a fim de ser deixado em evaporação lenta, no meio ambiente. O resíduo, constituído por um material de côr amarcla suja, foi de novo suspenso em álcool quente a $95 \%$ c, outra vez, deixado para evaporação natural.

De cada filtrado, após o tratamento com clorofórmio, foi separada uma amostra por vez, durante o andamento do processo, tendo sido mantida amostra do filtrado original, isto é, antes do tratamento com clorofórmio. Depois, tôdas as amostras foram submetidas a uma centrifugação durante 30 minutos a 2600 rotações, com o fim de separar o clorofórmio. Usou-se scmpre a porção do líquido que ficou na parte superior dos tubos do contrifugador. Esse processo foi exccutado repetidas vêzes. Em resumo, 
as percentagens resultantes dos sucessivos tratamentos com clorofórmio são as seguintes : a) $50 \%$ ou 425 para 873 lesões locais, obtidas em 18 fôlhas inoculadas de Nicotiana glutinosa, para o suco infetado tratado com o filtrado ; b) $68 \%$ ou 686 para 1011 em 24 fôlhas, após o primeiro tratamento com clorofórmio ; c) $56 \%$ ou 419 para 753 em 14 fôlhas, após o segundo tratamento; d) $48 \%$ ou 395 para 820 em 14 fôlhas, para o terceiro tratamento ; e) $14 \%$ ou 1 para 7 lesões locais em 6 fôlhas, após o quarto tratamento com clorofórmio. Pode-se daí concluir que, sob as condições destas experiências, o clorofórmio não extraiu completamente o inativador.

Foi tentada uma segunda experiência com filtrados já anteriormente utilizados para extração do inativador. Empregou-se o mesmo método do clorofórmio e com o mesmo processo geral. Os filtrados foram deixados em contacto com o clorofórmio durante 30 minutos, para cada tratamento. As amostras separadas foram centrifugadas e, depois, submetidas a teste, como anteriormente. Esse filtrado, isto é, o usado pela segunda vez, deu, sôbre 4 metades de fôlhas, 237 para 66 lesões locais para o testemunha, ou sejam $359 \%$ de lesões locais em relação ao tratamento testemunha. Visto que os três tratamentos de clorofórmio não deram grande diferença, foram todos agrupados, resultando a relação 935 e 206 lesões locais, respectivamente, ou sejam $454 \%$ em relação ao tratamento testemunha. Como já se mencionou anteriormente, o inativador nunca foi completamente extraído pelo clorofórmio. Todavia, nessa experiência acima descrita, aparentemente o inativador se perdeu durante a permanência do filtrado no ambiente de laboratório, durante os 40 dias em que aí foi mantido. Deve-se mencionar que as culturas do fungo, no ambiente de laboratório, perdem sua atividade depois de certo tempo de vegetação. $O$ maior número de lesões locais obtidas para a mistura, comparado ao extrato contendo vírus e não tratado, talvez possa ser explicado pela maior disseminação do "inoculum", facilitada pelo meio de cultura líquido que é o filtrado.

Uns poucos cristais, todavia, puderam ser obtidos dos diversos tratamentos com o clorofórmio. Esses poucos cristais, que tinham a aparência de agulhas, foram suspensos em $100 \mathrm{cc}$ de álcool. Êsse álcool foi diluído, para ser usado na inativação do vírus. A diluição de 1:10 deu 42 lesões locais para 64 , ou sejam $66 \%$ em relação ao testemunha. As diluições maiores, porém, sempre resultaram em elevado número de lesões locais em relação ao testemunha e, portanto, sem capacidade inativadora quando muito diluído.

\section{3 - SFPARAÇÃO DO INATIVADOR PRODUZIDO POR MEIO DE CENTRIFUGGAÇÃO E ULTRACENTRIFUGAÇÃO}

Uma cultura de 29 dias de idade, mantida no escuro e que, portanto, não tinha esporos formados, foi passada por uma filtração, a fim de separar o micélio. Uma segunda filtração, em papel de filtro, resultou em um filtrado claro, o qual foi centrifugado a 2600 rotações por minuto, em ambiente frio, durante uma hora e meia. Posteriormente, foi separada a parte superior e mantida em geladeira a $0^{\circ} \mathrm{C}$. A massa de micélio sôbre o papel de filtro 
foi lavada em água corrente, após o que foi moída em almofariz. Novamente foi filtrada em papel de filtro, e, do filtrado, uma parte foi centrifugada em ambiente frio, a 2600 r.p.m., durante meia hora. Como das outras ocasiões, as parcelas foram submetidas a teste em plantas de Nicotiana glutinosa. Os resultados foram, em número de lesões locais obtidas, de 10 e 105 para o tratado e testemunha respectivamente, ou sejam $10 \%$ a relação do filtrado da cultura para o extrato da planta com vírus, e de 6 e 77 , ou sejam $8 \%$ do filtrado centrifugado e misturado ao extrato com vírus, para o extrato sòmente. Da última parcela, já centrifugada a 2600 r.p.m., uma parte foi ultracentrifugada a 35000 r.p.m., durante uma hora. O liquido ultracentrifugado ainda contido no tubo de vidro foi separado em três parcelas, isto é, superior, média e inferior. Esta última deveria conter o inativador, caso a ultracentrifugação tivesse conseguido precipitá-lo ; foi suspensa em 3,5 cc de água destilada, sendo o tubo agitado e esfregado internamente com auxílio de bastonete de vidro com proteção de borracha na extremidade. As três partes foram submetidas a teste em relação ao extrato de planta infetada, tôdas a uma diluição de 1:100. Os resultados, em números de lesões locais obtidas, são, respectivamente, os seguintes, para as três partes, em relação ao extrato de planta com vírus : 8 para 38 , ou sejam $21 \%$ em relação ao testemunha, 4 para 24 ou $17 \%$ e 77 para 51 ou $151 \%$. Pelo que se vê, a ultracentrifugação não precipitou o inativador, sendo os resultados semelhantes aos obtidos pelos filtrados não tratados.

\section{4 - PRECIPITAÇÃO DO INATIVADOR PELA ACETONA}

Culturas de Trichoderma sp., mantidas desde o início, durante 30 dias no cscuro, foram filtradas, e o filtrado resultante, separado em amostras de 100 cc. Cada amostra de 100 ce foi tratada por acetona, na relação de duas vêzes o volume daquele (4). A mistura foi centrifugada a 2500 r.p.m., separada a parte superior e o precipitado foi novamente suspenso em água, em quantidade aproximada de um quinto do volume do líquido, após o tratamento com acetona. Essa suspensão foi de novo tratada com o dôbro do volume em acetona, outra vez centrifugada durante hora e meia a 2500 r.p.m. e, depois disso, separada a parte sobrenadante. O precipitado final foi novamente suspenso em $10 \mathrm{cc}$ de água para a prova de inativação. $O$ extrato normal de planta contendo o vírus foi diluído a 1:100 com a suspensão e, depois de ter agido durante dois minutos sôbre o vírus, o número de lesões locais foi de 5 e 18 , ou sejam $28 \%$ na relação de tratado para o testemunha. Com a permanência de uma hora de contacto do precipitado e do extrato da planta contendo o vírus, resultou em 2 e 41 lesóes, ou sejam $5 \%$.

\section{4 - DISCUSSÃO E CONCLUSÃO}

O fungo Trichoderma sp., cultivado em meio líquido, produziu uma substância capaz de inativar o vírus do mosaico comum do fumo, atingindo até $90 \%$ de inativação, sob certas circunstâncias. Johnson e Hoggan (2) mencionaram o fungo como inativador de vírus, produzindo seu efeito 
quando em meio de cultura contendo vírus do mosaico do fumo. Apesar de não mencionarem as percentagens dos resultados, afirmam não se ter portado o fungo como um excepcional destruidor do vírus. Comparando os resultados obtidos por êsses autores com os que se apresentam neste trabalho, o efeito maior aqui observado pode ser atribuído ao fato de se ter cultivado o fungo em meio líquido e se ter usado o filtrado da cultura para os testes de inativação do vírus. Pelo fato de o filtrado líquido ter mostrado ação inativadora, já após dois dias de cultura do fungo, se conclui que o inativador é produto de secreção externa.

A inativação se processa imediatamente após a mistura do filtrado ao extrato de planta contendo vírus, não tendo sido obtidos melhores resultados pelo contacto mais demorado.

Se as culturas se desenvolverem no laboratório, a uma temperatura de $22^{\circ} \mathrm{C}$, o poder de inativação decresce após o segundo dia de desenvolvimento, da mesma forma como o mencionado por Weindling (8) para a ação contra Rhizoctonia sp. Se, porém, a cultura fôr mantida em crescimento, em ambiente escuro, à temperatura de $27^{\circ} \mathrm{C}$, o inativador aumenta em concentração, pelo menos até aos 22 dias de desenvolvimento da cultura. Enquanto as culturas mantidas no escuro não dão formação a esporos do fungo, as mantidas à luz do dia formam esporos após o segundo dia de desenvolvimento, o que provàvelmente pode justificar a perda da capacidade inativadora para os filtrados destas, quando as culturas apresentam mais de dois dias de crescimento. Todavia, quando os filtrados de culturas mantidas no escuro foram transportados à luz do dia, perderam também a capacidade inativadora. Assim, a formação de esporos por si só não explica a perda de poder de inativação.

Segundo o método de Weindling, tentou-se isolar o inativador pelo uso de clorofórmio. O inativador não pôde ser completamente extraído do filtrado porque êste, após tratamento com clorofórmio, ainda mostrava alguma capacidade inativadora contra o vírus. Poder-se-ia, nas presentes experiências, estar à frente de um inativador diferente daquele que Weindling extraiu, e que se mostrava eficiente contra o fungo Rhizoctonia sp.

Por meio de ultracentrifugação, não foi possível conseguir a separação do princípio inativador.

Empregando o método de precipitação pela acetona, segundo Takahashi, foi obtido um precipitado esbranquiçado, que mostrou capacidade de inativação sôbre o vírus do mosaico de fumo.

\section{S U M M A R Y}

Trichoderma sp. grown in liquid medium produced a substance which has caused up to $90 \%$ reduction in the infection capacity of the tobacco mosaic virus, mcasured in number of loeal lesions on Nicotiana glutinosa half leaf inoculations. Under the present experiments the fungus has been grown in liquid medium and the filtrates used in inactivation tests on the virus. From the fact that the liquid filtrate showed inactivation power after only two days of culture it is concluded that the inactivation is of the nature of a secretion of the fungus into the liquid medium.

The inactivation proceeded within 2 minutes after mixture of the culture extract with the virus, no better results were obtained if the mixtures allowed to stand for a longer period of time. 
If cultures were grown in the light in the laboratory the inactivation power decreased after the second day as was found by Weindling (8), for the effect on Rhizoctonia sp. If grown in the dark the inactivator continues to increase in concentrations for at least 22 days. In the dark no spores formation could be observed. Physiological activity associated with spores formation may be the reason for the loss of inactivator in day light grown cultures where spores start to be formed after the second day of growth.

Extraction of the inactivator with chloroform was attempted according to Weindling's method. The inactivator could never be completely extracted since the treated filtrate kept showing inactivation on tobacco mosaic virus. This suggests that the inactivator for the virus may be a different from the one found by Weindling against Rhizoctonia sp. filtrate.

By ultracentrifugation at 35,000 r.p.m. no inactivator could be obtained from the

Using Takahashi's acetone method a whitish precipitate could be obtained which showed an inactivation of tobacco mosaic virus.

\section{LITERATURA CITADA}

1. Johnson, J. Plant virus inhibitors produced by microorganisms. Science (ns.) 88: 552-3. 1938.

2. Johnson, J. and Ismé A. Hoggan. The inactivation of ordinary tobacco mosaic virus by microorganisms. Phytopathology 27: 1014-1027. 1937.

3. Rawlins, T. E. Em Phytopathological and botanical research methods. John Wiley \& Sons, N. Y.

4. Takahashi, William N. A virus inactivator from yeast. Science 95: 586-7. 1942.

5. Waksman, Selman A. and Elizabeth S. Horning. Distribution of antagonistic fungi in nature and their antibiotic action. Mycologia 35: 47-65. 1943.

6. Weindling, R. Studies on a lethal principle effective in the parasitic action of Trichoderma lignorum on Rhizoctonia solani and other soil fungi. Phytopathology 24: 1153-1179. 1934.

7. Weindling, R. Isolation of toxic substances from the culture filtrate of Trichoderma and Gliocladium. Phytopathology 27: 1175-1177. 1937.

8. Weindling, R. Toxins of Gliocladium and Trichoderma. Phytopathology 31:9911003. 1941.

9. Weindling, R. and O. H. Emerson. The isolation of a toxic substance from the culture filtrate of Trichoderma. Phytopathology 26: 1068-1070. 1936. 